http://www.jfas.info

\title{
TIME REVIEW IN CRIMINAL CASES
}

\author{
H. A. Azarian
}

Faculty Member of Payam Noor University of Zabol

\begin{abstract}
According to the definition of punishment under the new law which includes also the preventive punishments, it seems different types of time review is including the preventive punishments in the fifth book of the Penal Code Act of 1375. Due to the difficulty of separation between the prison and the preventive punishments from one side of the court procedure was under dispute on the other hand did not have certain legal effect (other than time), merging deterrent penalties in punishment is positive the new law. But the difficulty in separating continues to determine the "authoritative canonical sanctions" and excluding it from pursue time. Knowing the time is important for detectives because since the statute of limitations on time reviewing crimes or in case of cessation of prosecution or endowments run, the lack of effective required actions will be considered.
\end{abstract}

Keywords: Time review; criminal cases; different types of time review.

Author Correspondence, e-mail: authorC@mail.com

doi: http://dx.doi.org/10.4314/jfas.v8i2s.170

\section{INTRODUCTION}

One of the issues that are rarely discussed today in legal circles is including the time in criminal cases. Perhaps it is the result of Islamic law approach to this issue. But more 
importantly, is the resistance against the issue that including it in all criminal cases initially denied and then admitted it is merely the preventive punishments. To what extent can they enter the legal establishment of punitive sanctions that range, there are still serious discussions have not been respected by lawyers and jurists in this regard. But ambiguity in the definition of legislative is deterrent penalties of the dispersion of votes in criminal trials. The scope of the incoherence of the vote in some cases is drawn to Supreme Court and has led the Authority to the ballot issue. The apparent reason is that the current state of the legal definition of the crime deterrent, unity is not available in the identification of this type of crime and theoretical discussions are typically people with their beliefs function. Because in some cases are sometimes placed in the sector and many crimes sometimes even turn away from crime deterrent. It is a fact that the classifications of crimes in the penal code do not make it easy to implement laws on time, on the other hand, it does not yield clear boundary between the preventive punishments and ta'zir. The author tries in this study; first, theoretical discussion, including the time review and then have a glimpse into its place in the Iranian and French laws.

a- Legal doctrine in relation to the inclusion of time in criminal cases

In short, we can say, first fulfillment school (Italian) criticized including time on this type of claims and refused the minimum to make it a habit of criminals and criminals who have a tendency to commit crime. Some critics argued were that if we want to investigate the useful grounds of social defense against criminals, it is very objectionable. Not because it reduces the risk of criminals, but generally preclude their presence in the community. In contrast, proponents believed that, including time in penalty and criminal proceedings in this regard is justified that, if the aim of establishing peace and security be followed in the society in a specific time period it is better than we prosecute the forgotten crime again and revive it. On the other hand, if the case continues to be the possibility of criminal prosecution and punishment applicable throughout the life he always lives in anxiety and concern, while that may actually is repented of his act. However, this step takes for a long time, for example, over time, including 20 years in crimes which causes 20 -years of ignorance for criminal. An alternative explanation of including time in criminal matters is the idea of negligence and 
negligent prosecution and punishment of offenders in the community. The community loses its legal right to enforce it because no longer it is useful. In fact, one of the main reasons including the time in criminal matters based on external factors that are reducing evidence analysis. Clearly, the passage of time from the moment of the crime, evidence is entirely disappeared or at least its value is reduced. Therefore, several years after the crime, discover the works and evidence, searching for witnesses and those who have forgotten or is likely or subject memory recall obscure it extremely difficult. More importantly, dealing with criminal cases that a long time is passed provides the risks for wrong judicial. Therefore, to avoid this situation and with the interests of the community in establishing justice, inclusiveness over time can prevent these errors in judgment.

B) Inclusion of time in France criminal law

According to French civil law, litigation runs in a particular period (la prescription de l'action publique) (in accordance with the general rule, 30 years under article 226 Civil Procedure Code, except in the case of non-contractual obligations before the deadline to 10 years act of 12270 approved in July 1985 was decreased) and then also can no longer be addressed. This is what we call including time or lapse claims. This is also seen in criminal law. Criminal proceedings cannot be brought unless in a particular period and then the case this not presentable. Therefore, the prosecution of criminals after that cannot be allowed. Articles of 7 , 8 and 9 of French criminal procedure law has established that in criminal cases, including time should be determined carefully in all criminal cases, because this issue not only in terms of work but also in terms of objectives is different. Thus according to French criminal law, including applicable time from two perspectives:

First, the severity of the punishment, the crime including time in 20 years, the misdemeanor five years, in violation of 3 years.

Secondly, in terms of crime, the crime, including time in 10 years, misdemeanors 3 years, and in violation it would be only a year even if their offense is the basis for committing misdemeanors.

However, while a French committed crime outside the country, including France predicted over time is the same as in criminal law. Of course dates announced alongside the general 
rules; specific rules have been observed in the deficit deadlines. For example, 6 months since the announcement of election results for offenses under Article 114 of the electoral law, three months for misdemeanors and infractions of the Law of Freedom of the Press Act of 29 July.

C) Inclusion of time in the Iranian Penal

Before the Islamic Revolution in Iran, including civil and criminal laws had been accepted over time. But in 1361 the Supreme Court by asking the question "whether the lack of demand and religion at the court hearing the case according to Article 731 of the Civil Procedure Code and Article 12, over time in the Code of Criminal Procedure is contrary to Sharia law or not? Asked the Guardian Council to declare its opinion in this case, Guardian Council according to the No. 7257 on 17 Feb of 1982 replied that:

"The honorable Supreme Judicial turning to a number 50655 dated 17 Jan 1982, article 731 of the Civil Procedure Code, the jurists on the Guardian Council over time in the meeting discussed were examined and it provided that the majority of Council scholars, after a period of time (10 years, 20 years, 3 years, 1 year, etc.) cannot be heard in court case. It is diagnosed contrary to the Sharia. The Guardian Council Secretary, Ayatollah Safi

Thus, over time, including the issue was contrary to Sharia law, but in practice it is preferred in some cases impose judicial procedures, for example, the inclusion of time in the check holder referred against the endorser contested in Article 315 of the Commercial Code. Meanwhile, in the criminal realm resistance on the part of Muslim legislators about inclusion over time is observed, but with new developments in this matter, he finally Code of Criminal Procedure Article 173 General and Revolutionary Courts Act 1378 was accepted on the preventive punishments. Article 173 provides as follows:

In those punishable by law, the punishment is preventive or corrective measures order and the date of expiry of the crime to demand prosecution of union, or from the date of expiry of the deadline mentioned in the first sentence the prosecution has not resulted it will cease the prosecutions. A - The maximum penalty prescribed for more than three years in prison or a fine of more than one million Rials with the expiration of ten years

B - Maximum punishment less than three years imprisonment or a fine up to one million Rials with the expiration of five years 
C- Punishment other than imprisonment or a fine of expiry for three years

Note - In cases where the punishment provided for the offense is imprisonment or a fine or whipping or jail term of three criteria will be taken into account. "

But this new approach also was not causing profound changes in this regard, because on the one hand the ambiguity of the preventive punishments and the lack of clear boundaries between these crimes and other crimes in the Penal Code, today we face issued the criminal trials of Motahaft vote. While it seems like this article sometimes in certain crimes verdict would provide cessation of prosecution and the fact that they have uncertain border. For example, in the case of $80 / 155 / 10$ referred to in Branch 10 of the Appeals province issue revised the verdict issued by Branch 131 19.9.79 issued by General Court on the charge of illegal possession of government property, the appeal court by arguing that "the defendants' objection on the part of the organization's accusations, because of the date and time of the crime, in 1992 and 1993, and the report and began to prosecute the accused in that case lapse of Article 173 the Criminal Act of 1999 is not tracking thus by violating the first verdict and issuing cessation of prosecution" was accepted. In another lawsuit in Branch 27 of Kermanshah General Court on the subject of the complaint of 80/609 classified file charges against the accused ... to the illegal occupation of government property during the letter of No. 1518 10/24/80 by arguing that "beside the authenticity of the papers and evidence presented in the case to the relevant operation ended in May 1995 and deterrent penalties, including due time of article 173' and the verdict is issued on cessation of prosecution. In this regard, the General Court in Urumieh in case No. 73/765/1 issue of complaints the department of ---against the accused of company misappropriated state property (embezzlement) during lawsuit of No. 162304.11 .1380 by arguing that "regardless of all normal and preliminary investigations indicate Court insert statements for regulatory parliament representing the rights of the plaintiff and the defense department and their lawyers accused the court---others accused in the alleged crime ...... considering that punishment is not legal meaningfully ta'zir derived from Article 17 of the IPC and not drawing boundary with Article 16 of the Act and the provisions of Article 2 judicial ruling is diagnosed preventive, and in view of the case and considering that the conditions set forth in Article 173 according to the researcher's 
Court, the lawsuit, filed in Criminal Matters court regarded the subject over time, according to Article 173 paragraph 6 of Article 6 of the written law and the cessation of prosecution of criminal defendants " was issued. But while a panel of Supreme Court precedent 03.07.1381 No. 659 has commented that according to Article 173 of the Criminal Procedure Code offenses that their punishment is a deterrent type of prosecution, they shall be suspended by reviewing although the invasion of national territory and the forcible seizure of land used by the Article 17 of the IPC has been a deterrent punishment but because the ongoing crime will continue until the occupation will not be subject to lapse but despite the verdict of Eighth Branch of the Court of Appeal province forth solely in terms of the Third Branch of the General Court established a violation of the cessation of prosecution to the majority of the board of the Supreme Court and hence legal recognition, document to Article 270 of the said Act is binding on similar cases, the Supreme Court and courts". In this regard, a panel of Supreme Court precedent No. 696 dated 12.04.2006 on the subject of the sentence, including time of other money transfer scam, has decreed: ""reprimand legal definition of a substance in Note 2 General and Revolutionary Court Hearing Procedures in Penal Matters Act of 1378 contained and dissuasive penalties in accordance with Article 17 of the Penal Code, discipline or punishment by the state in order to maintain order and respect the interest of the community is assigned. Since the legislator's, knowing that the person's property is transferring, it is considered tantamount to fraud and deserves punishment and proceed to the nature of the manifestations of taking is also considered void that was considered religiously prohibited. The majority of non-public Supreme Court, the crime of property transfer issues, including the provisions of Article 173 of the law is written out and the verdict of third branch Appeals Court Golestan Province had valid diagnosis. "

In the new Penal Code, three types over time, there are complaints time, tracking time and penalties time. Over time the complaint, in the past only was recognized for crime of overdrawn check. Over time, complaints of non-compliance, the lack of attention to the legal deadline for filing a complaint, the waiver is sued. For sentenced and negligible crimes, the deadline for complaints, one year from the date of the crime. If your reasons are probative, but not according to Deadline, the judicial authorities may not have legal rights. In Law on the 
Organization and Procedure of the Court of Administrative Justice Act of 2013 is also the deadline for complaints to administrative courts' rulings, including municipal committees and the Board of Administrative Violations is three months from the date of notification of protest vote.

Today the above-mentioned deadline, and are expected to conform full information on the event, people from the judiciary to problems will not be in the near future. This deadline, for the first time was imposed this year limiting the plaintiff's right of action because according to the former rules, the deadline for filing a complaint about an offense except on the overdrawn check, did not exist.

If you inform the complainant of the date of the crime, a year has passed and the plaintiff did not file a complaint, the crime can be sentenced to lapse, and the petitioners will not have the right to a criminal complaint, however, if the date of the crime in prison, as the case may elapse between 3 and 15 years to register a complaint and not the complainant, although failing to inform him of the crime, the crime is lapse prosecution.

\section{CONCLUSION}

According to the author, including threads over time have ambiguities arising from the interpretation of the legal definition of punishment and deterrent sanctions are in 16 and 17 Articles of IPC. Therefore, prevent the continuation of this trend is the responsibility of the prosecutor general that conflict with the public votes on a single issue of demanding the Supreme Court precedents. However, the recent situation considerably, even to a panel of Supreme Court definition quality without providing comprehensive, continuous crimes lapse unaware that indicates the failure of law. As well as cases since the beginning of time, reason suspend or terminate over time, also need to review and these discussions should also be considered in the legislation. And finally must paid more attention include benefits in Criminal Matters and its development over time.

In short, all punishment crimes and forgivable include time lapse of complaint and is equal with non-compliance with the deadline of one year of waiver of the complaint. Complain to the court within three months as well, with few exceptions, can be considered a form of time 
complaints.

Based on Article 113 of the new Penal Code, cease prosecution, sentencing or punishment, hinder the rights of private claims and the victim of crime can sue to the court.

\section{REFERENCES}

[1] Stefani G., Levasseur G, Bouloc B., Procédure pénal .Dalloz, 2004 ed, 19 G.

[2] Preadel J, Manuel de procédure, Cujas,12, ed.

[3] Hamidreza Mirzajani, 2006, Mr. Makram laws of the land bank of ideas on the site of the Tehran judiciary.

[4] Islamic Penal Code 2013.

[5] Code of Criminal Procedure 2013.

\section{How to cite this article:}

Azarian H A. Time review in criminal cases. J. Fundam. Appl. Sci., 2016, 8(4S), 2110-2117. 